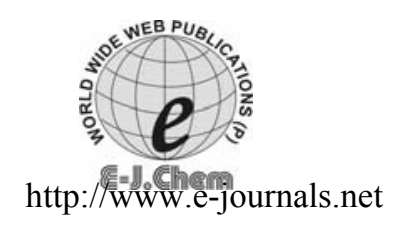

ISSN: 0973-4945; CODEN ECJHAO

E-Journal of Chemistry

2012, 9(1), $15-20$

\title{
Study of Physicochemical Parameters of Groundwater Quality of Kopargaon Area, Maharastra State, India during Pre-monsoon and Post-monsoon Seasons
}

\author{
SUNITA R. DANDWATE \\ Department of Engineering Science (Physics) \\ Sanjivani Rural Education Society's College of Engineering, Kopargaon-423603, India \\ srdandwate@gmail.com
}

Received 28 July 2010; Revised 5 December 2010; Accepted 20 January 2011

\begin{abstract}
The physicochemical parameters were studied for water samples collected from different locations in Kopargaon area; It is one of the important taluka of Ahmednagar district, Maharastra state, India. The main purpose of the study was to ascertain the quality of water for drinking from selected locations. Assessment of water quality was done by comparing the parameters with standard values prescribed by different agencies. Most of the parameters were found within permissible limits of above standards. Correlation coefficient ' $r$ ' was calculated for these parameters.
\end{abstract}

Keywords: Kopargaon, Physicochemical parameters, Pre-monsoon, Post-monsoon, Correlation coefficient

\section{Introduction}

Groundwater is the major source of drinking water in both urban and rural areas. The importance of groundwater for the existence of human society cannot be overemphasized ${ }^{1}$. The modern civilization, industrialization, urbanization and increase in population have laid to the fast degradation of our groundwater quality ${ }^{2}$. Groundwater is about $20 \%$ of the world resource of fresh water and widely used for various purposes. Only about $1 \%$ of all of fresh water is available from rivers, ponds, lakes $e t c^{3}$. The quality of water depends upon various chemical constituents and their concentration generated by fertilizers, industrial waste, garbage or domestic waste.

The groundwater analysis for physical and chemical properties is very important for public health studies. These studies are also main part of pollution studies in the environment ${ }^{4}$. 
Literature survey shows that there has been no published report in ground water quality studies in rural parts of Kopargaon. This has created the focus to select the present work over five sampling stations in and around kopargaon city. Kopargaon is a taluka place in Ahmednagar district and is well developed in industrial, educational and agricultural fields. Its location is longitude $74028^{\prime} 60 \mathrm{E}$ and latitude $19052^{\prime} 60 \mathrm{~N}$. The climate of this area is hot and humid and the average rainfall ${ }^{5}$ is about $58.7 \mathrm{~cm}$. The range of temperature is between $39^{\circ} \mathrm{C}$ and $11.7^{\circ} \mathrm{C}$.

\section{Experimental}

Water samples from the selected sites were collected from April-2009 to March-2010. Samples were taken in 2 liter capacity pre-cleaned polythene bottles ${ }^{6-7}$. Collection and analysis of samples was done monthly for the measurement of temperature, $\mathrm{pH}$, electrical conductivity (EC), total dissolved solids (TDS), turbidity, total hardness (TH), chloride contents, total alkalinity and salinity. Data analysis was further done for pre-monsoon and post-monsoon seasons. Out of five samples one was municipal sample (from Kopargaon town), one was tap drinking water (from College of Engineering, Sahajanandnagar) and remaining three were dug well samples (from Ravande, Kolpewadi and Kanhegaon). All samples were properly labeled as $S_{1}, S_{2}, S_{3}, S_{4}$ and $S_{5}$ and record was prepared as indicated in Table 1 .

Table 1. Area, Source and distance from central place

\begin{tabular}{|c|c|c|c|}
\hline $\begin{array}{l}\text { Sampling } \\
\text { Station No. }\end{array}$ & Area & Source & $\begin{array}{c}\text { Approximate distance }(\mathrm{km}) \\
\text { (From first station as a central place) }\end{array}$ \\
\hline $\mathrm{S}_{1}$ & Sahajanandnagar & Tap & 00 \\
\hline $\mathrm{S}_{2}$ & Kopargaon Town & $\begin{array}{l}\text { Municipality } \\
\text { Supply }\end{array}$ & 03 \\
\hline $\mathrm{S}_{3}$ & Ravande & Dug Well & 15 \\
\hline $\mathrm{S}_{4}$ & Kolpewadi & Dug Well & 18 \\
\hline $\mathrm{S}_{5}$ & Kanhegaon & Dug Well & 22 \\
\hline
\end{tabular}

A multi-parameter water testing kit "PCS Tester 35" (Eutech make) was used for the measurement of temperature, $\mathrm{pH}, \mathrm{EC}$, TDS and salinity. A Labtronics make nephelometer (Model No. 34) having range 0-200 NTU was used for the measurement of turbidity. TH was measured by EDTA (Ethylenediaminetetraacetic acid) method $^{8}$ in which EBT (Erichrome black-T) is used as an indicator. Chloride contents were measured by a titrative Mohr's method. Total alkalinity was also measured by a titration method using methyl orange and phenolphthalein as indicator. All the chemicals used for the analysis were of AR grade. To find out the correlation between any two measured parameters a correlation analysis has been carried out with the help of correlation co-efficient ' $r$ '.

\section{Results and Discussion}

The standard values of different water quality physicochemical parameters ${ }^{9-10}$ and units employed are listed in Table 2. In present study the physicochemical parameters were studied for five different water samples and were divided into pre-monsoon and postmonsoon groups as listed in Table 3.

\section{Temperature}

Cool water is generally more potable than warm water. High water temperature enhances the growth of microorganisms and may increase taste, odour, color and corrosion problems (WHO). The temperature was found to be in the range between 25.5 and $31.4{ }^{\circ} \mathrm{C}$. The higher values of temperature are noticed especially for pre-monsoon measurements. 
Table 2. The physicochemical parameters of various samples for pre-monsoon and postmonsoon seasons (parenthesis indicates units / desirable limits)

\begin{tabular}{|c|c|c|c|c|}
\hline \multicolumn{2}{|l|}{ Parameter } & Temperature, ${ }^{0} \mathrm{C}$ & $\mathrm{pH}(6.5-8.5)$ & $\mathrm{EC}\left(7.1 \times 10^{2} \mu \mathrm{S}\right)$ \\
\hline \multirow{5}{*}{ Pre-monsoon } & $\mathrm{S}_{1}$ & 26.9 & 8.73 & 1069 \\
\hline & $\mathrm{S}_{2}$ & 26.7 & 8.73 & 1047 \\
\hline & $\mathrm{S}_{3}$ & 31.4 & 7.84 & 1400 \\
\hline & $\mathrm{S}_{4}$ & 30 & 8.45 & 503 \\
\hline & $\mathrm{S}_{5}$ & 28 & 8.62 & 917 \\
\hline \multirow{5}{*}{ Post-monsoon } & $\mathrm{S}_{1}$ & 25.5 & 8.88 & 1081 \\
\hline & $\mathrm{S}_{2}$ & 26 & 8.2 & 410 \\
\hline & $\mathrm{S}_{3}$ & 26.2 & 8.17 & 808 \\
\hline & $\mathrm{S}_{4}$ & 26 & 8.72 & 545 \\
\hline & $\mathrm{S}_{5}$ & 26.3 & 8.81 & 1096 \\
\hline Parameter & & TDS, $500 \mathrm{mg} / \mathrm{L}$ & Turbidity (5 NTU) & $\mathrm{TH}, 300 \mathrm{mg} / \mathrm{L}$ \\
\hline \multirow{5}{*}{ Pre-monsoon } & $\mathrm{S}_{1}$ & 756 & 1.8 & 357 \\
\hline & $\mathrm{S}_{2}$ & 743 & 1.6 & 314 \\
\hline & $\mathrm{S}_{3}$ & 993 & 1.8 & 1215 \\
\hline & $\mathrm{S}_{4}$ & 356 & 0.2 & 329 \\
\hline & $\mathrm{S}_{5}$ & 837 & 1.6 & 375 \\
\hline \multirow{5}{*}{ Post-monsoon } & $\mathrm{S}_{1}$ & 767 & 6.6 & 629 \\
\hline & $\mathrm{S}_{2}$ & 292 & 0.2 & 257 \\
\hline & $\mathrm{S}_{3}$ & 572 & 7.2 & 671 \\
\hline & $\mathrm{S}_{4}$ & 385 & 8.5 & 486 \\
\hline & $\mathrm{S}_{5}$ & 778 & 7.7 & 557 \\
\hline \multicolumn{2}{|l|}{ Parameter } & $\begin{array}{l}\text { Chloride content, } \\
250 \mathrm{mg} / \mathrm{L}\end{array}$ & $\begin{array}{r}\text { Tot. Alkali } \\
200 \mathrm{mg} /\end{array}$ & $\begin{array}{l}\text { Salinity } \\
\mathrm{mg} / \mathrm{L}\end{array}$ \\
\hline \multirow{5}{*}{ Pre-monsoon } & $\mathrm{S}_{1}$ & 249 & 230 & 527 \\
\hline & $\mathrm{S}_{2}$ & 606 & 130 & 514 \\
\hline & $\mathrm{S}_{3}$ & 1355 & 100 & 700 \\
\hline & $\mathrm{S}_{4}$ & 444 & 80 & 254 \\
\hline & $\mathrm{S}_{5}$ & 326 & 76 & 348 \\
\hline \multirow{5}{*}{ Post-monsoon } & $\mathrm{S}_{1}$ & 182 & 120 & 535 \\
\hline & $\mathrm{S}_{2}$ & 151 & 60 & 199 \\
\hline & $\mathrm{S}_{3}$ & 151 & 80 & 396 \\
\hline & $\mathrm{S}_{4}$ & 93 & 90 & 263 \\
\hline & $\mathrm{S}_{5}$ & 245 & 90 & 544 \\
\hline
\end{tabular}

$p H$

The $\mathrm{pH}$ serves as an index to denote the extent of pollution by acidic or basic waste. The $\mathrm{pH}$ values were found between 7.84 and 8.88 . The $\mathrm{pH}$ shows slightly alkaline nature of all samples. 
Table 3. Correlation matrix for water quality parameters (Pre-monsoon)

\begin{tabular}{cccccccccc}
\hline Parameter & Temperature & $\mathrm{pH}$ & $\mathrm{EC}$ & $\mathrm{TDS}$ & Turbidity & $\mathrm{TH}$ & Chloride & Alkalinity & Salinity \\
\hline Temperature & 1.00 & -0.9268 & 0.10108 & 0.04152 & -0.3142 & 0.7638 & 0.7279 & -0.5633 & 0.1659 \\
pH & & 1.00 & -0.4641 & -0.3773 & -0.04156 & -0.9485 & -0.9096 & 0.4015 & -0.346 \\
EC & & & 1.00 & $0.9353^{*}$ & 0.8835 & 0.7191 & 0.6552 & 0.2895 & $0.9609^{*}$ \\
TDS & & & & 1.00 & $0.9225^{*}$ & 0.6315 & 0.5223 & 0.1319 & $0.8013^{*}$ \\
Turbidity & & & & & 1.00 & 0.351 & 0.2444 & 0.4487 & 0.7639 \\
TH & & & & & & 1.00 & $0.9354^{*}$ & -0.2003 & 0.7422 \\
Chloride & & & & & & & 1.00 & -0.3125 & 0.7177 \\
Alkalinity & & & & & & & & 1.00 & 0.3679 \\
Salinity & & & & & & & & & \\
\hline
\end{tabular}

${ }^{*}$ Highly significant correlation between EC \& TDS, EC \& Salinity, TDS \& Turbidity, TDS \& Salinity, TH \& Chloride

Table 4. Correlation matrix for various water quality parameters (Post-monsoon)

\begin{tabular}{cccccccccc}
\hline \multirow{2}{*}{ Parameter } & \multirow{2}{*}{ Temperature } & $\mathrm{pH}$ & $\mathrm{N}$ EC & \multirow{2}{*}{ TDS } & Turbidity & TH & Chloride & Alkalinity & Salinity \\
\hline Temperature & \multirow{2}{*}{1.00} & -0.3848 & -0.1313 & -0.1661 & 0.1093 & -0.0656 & 0.186 & -0.636 & -0.1305 \\
pH & & 1.00 & 0.6117 & 0.6113 & 0.575 & 0.3323 & 0.3207 & 0.8143 & 0.6107 \\
EC & & & 1.00 & $.9999^{*}$ & 0.5586 & 0.763 & 0.7605 & 0.7426 & $0.9999^{*}$ \\
TDS & & & & 1.00 & 0.5545 & 0.7599 & 0.7634 & 0.7412 & $0.9999^{*}$ \\
Turbidity & & & & & 1.00 & 0.8036 & 0.0415 & 0.6231 & 0.5505 \\
TH & & & & & & 1.00 & 0.2444 & 0.6823 & 0.7562 \\
Chloride & & & & & & & 1.00 & 0.2215 & 0.7672 \\
Alkalinity & & & & & & & & 1.00 & 0.7387 \\
Salinity & & & & & & & & & \\
\hline
\end{tabular}

${ }^{*}$ Highly significant correlation between EC \& TDS, EC \& Salinity, TDS \& Salinity 
$E C$

Electrical conductivity is a measure of water's capacity to convey an electric current. This property is related to the total concentration of ionized substances in water. The more dissolved salts in water, the stronger is current flow and higher the EC. In short, EC of water increases with salts. In present study EC values were found within the range of $503 \mu$ Siemens to $1400 \mu$ Siemens and $292 \mu$ Siemens to $1096 \mu$ Siemens for pre-monsoon and post-monsoon seasons respectively.

\section{$T D S$}

TDS indicates the salinity behavior of groundwater ${ }^{11}$. TDS of ground water is mainly due to vegetable decay, evaporation, disposal of effluent and chemical weathering of rocks. In the present investigation the TDS was found up to $993 \mathrm{mg} / \mathrm{L}$ and $778 \mathrm{mg} / \mathrm{L}$ for pre- and postmonsoon season respectively.

\section{Turbidity}

Turbidity in water is the reduction of transparency due to the presence of particulate matter such as clay or slit, finely divided organic matter etc. These can cause light to be scattered or absorbed rather than transmitted in straight lines through the sample. In present study turbidity was found between 0.2 and $1.8 \mathrm{NTU}$ for pre-monsoon and 0.2 to $8.5 \mathrm{NTU}$ for post-monsoon measurements. Turbidity of S1, S3, S4 and S5 was found with high values than that prescribed by IS: 10500 .

\section{TH}

Hardness of water is the capacity of water to react with soap, hard water requiring considerably more soap to produce lather. Hardness is one of the important properties of groundwater from utility point of view for different purposes ${ }^{12}$. For potable water the TH should be limited up to $300 \mathrm{mg} / \mathrm{L}$ and maximum permissible value is $600 \mathrm{mg} / \mathrm{L}$ (Table 2). The TH values were found within permissible range except for $\mathrm{S} 3$.

\section{Chloride contents}

The maximum permissible value of chloride content is $1000 \mathrm{mg} / \mathrm{L}$ (Table 2). Except S3, all samples were found to be having concentration of chloride within limit.

\section{Total alkalinity}

The desirable limit of alkalinity is $200 \mathrm{mg} / \mathrm{L}$ and maximum permissible limit is $600 \mathrm{mg} / \mathrm{L}$ (Table 2). The alkalinity values were found within permissible range for all samples.

\section{Salinity}

The salt content of water is termed as salinity. TDS and EC are proportional to salinity. In present investigation, salinity was found between 254 and $700 \mathrm{mg} / \mathrm{L}$.

\section{Statistical analysis}

Interrelationship studies between different values are very helpful tools in promoting research and opening new frontiers of knowledge. The study of correlation reduces the range of uncertainty associated with decision making ${ }^{1,11}$. The correlation co-efficient ' $r$ ' was calculated using the equation

$$
r=\frac{\sum x y}{\sqrt{\sum_{x} 2 x \sum_{y} 2}}
$$

Where $\mathrm{x}=\mathrm{X}-\mathrm{X}^{-}$and $\mathrm{y}=\mathrm{Y}-Y^{-}, \mathrm{X}$ and $\mathrm{Y}$ represent two different parameters $X^{-}=$Mean value of $\mathrm{X} ; Y^{-}=$Mean value of $\mathrm{Y}$. The values of correlation co-efficient ' $r$ ' for different parameters for pre-monsoon and post-monsoon seasons are as shown in Table 3 and Table 4 respectively. 


\section{Conclusion}

Water quality parameters were found deviating for different samples. All water samples were found with alkaline trend and with slightly higher values of TDS than desirable value. The water sample S3 was found unfit for drinking due to high values of EC (WHO standards ${ }^{11}$ ), TH and chloride contents. It is recommended that the water of S3 should be used after proper treatment.

\section{References}

1. Shyamala R, Shanthi M and Lalitha P, E-J Chem., 2008, 5(4), 924-929.

2. Agrawal R, RJC, 2009, 2(4), 969-971.

3. Wagh C V, Kokate S J, Aher H R and Kuchekar S R, RJC., 2009, 2(1), 234-242.

4. Jafari A, Mirhossaini H, Kamareii B and Dehestani S, Asian J Appl Sci., 2008, 1, 87-92.

5. $\quad$ Dandwate R R and Dandwate S R, Trends in Life Sciences (India), 2007, 22(2), 91-96.

6. Standard Method for Estimation of Water and Wastewater, American Public Health Association, Washington, D.C. 1989.

7. $\quad$ Bhagat $\mathrm{P} \mathrm{R}, \mathrm{RJC}, 2008, \mathbf{1 1}(\mathbf{1}), 195-197$.

8. Sharma B K, Engineering Chemistry, Krishna Prakashan Media (P) Ltd., Meerut 2002.

9. Garg D, Kaur R, Chand D, Mehla S K and Singh R V, RJC., 2008, 1(4), 743-750.

10. Indian Standard Specifications for Drinking Water IS: 10500.

11. Patil V T and Patil P R, E-J Chem., 2010, 7(1), 111-116.

12. Gupta D P, Sunita and Saharan J P, Res., 2009, 1(2), 1-5. 


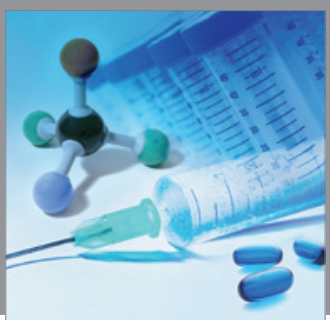

International Journal of

Medicinal Chemistry

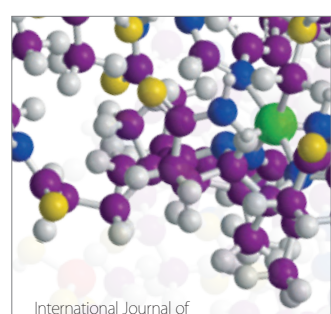

Carbohydrate Chemistry

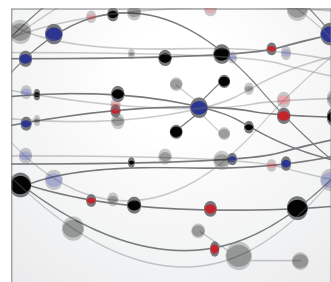

The Scientific World Journal
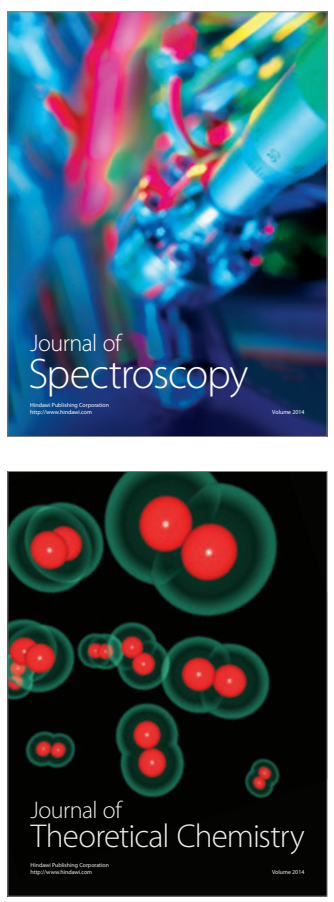
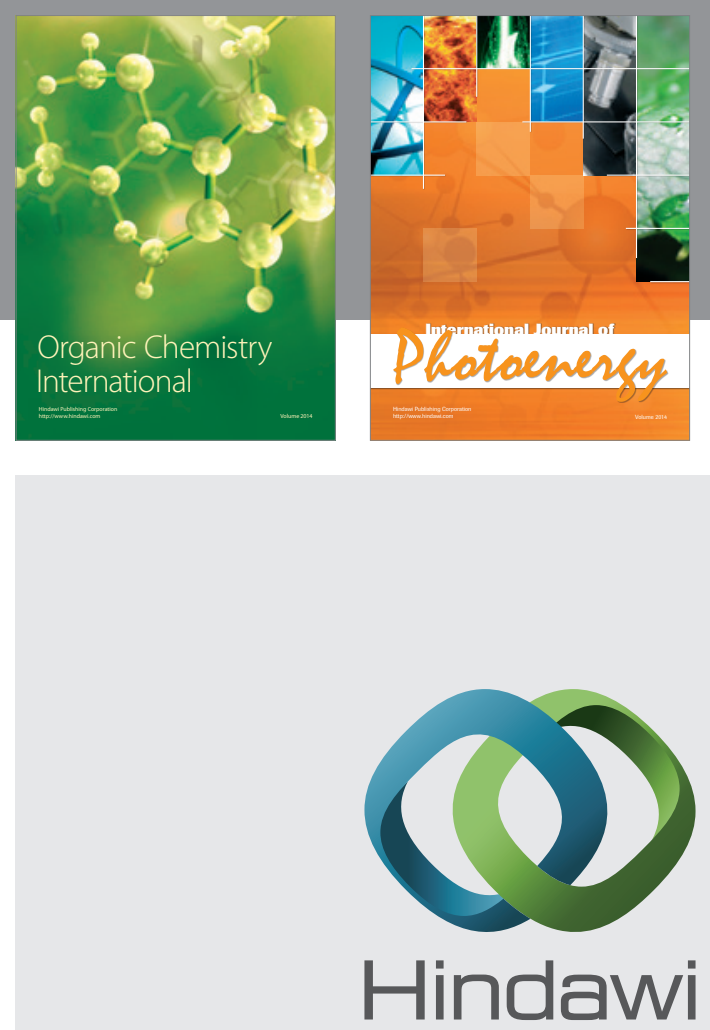

Submit your manuscripts at

http://www.hindawi.com
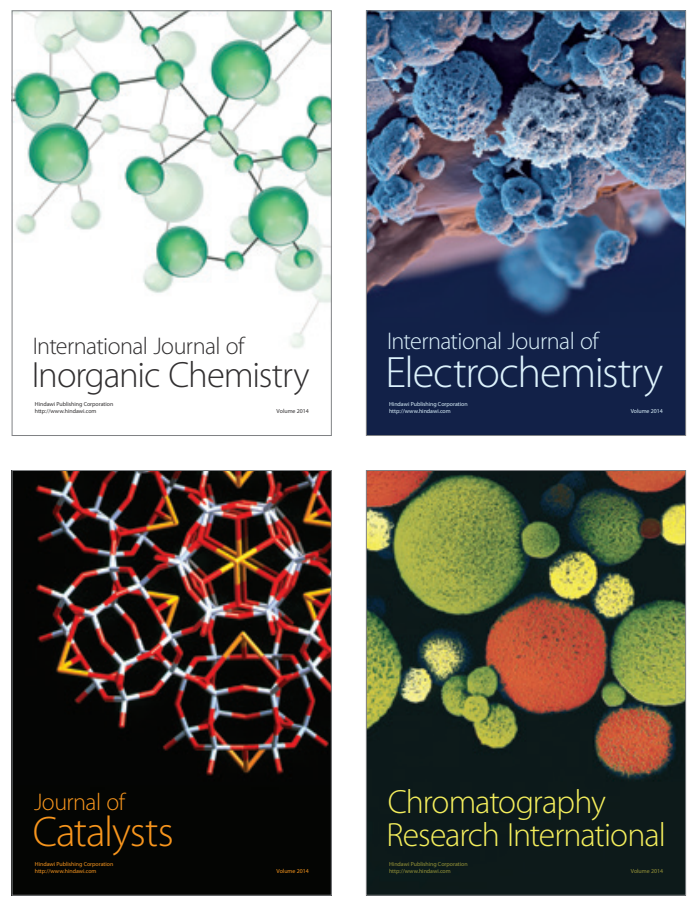
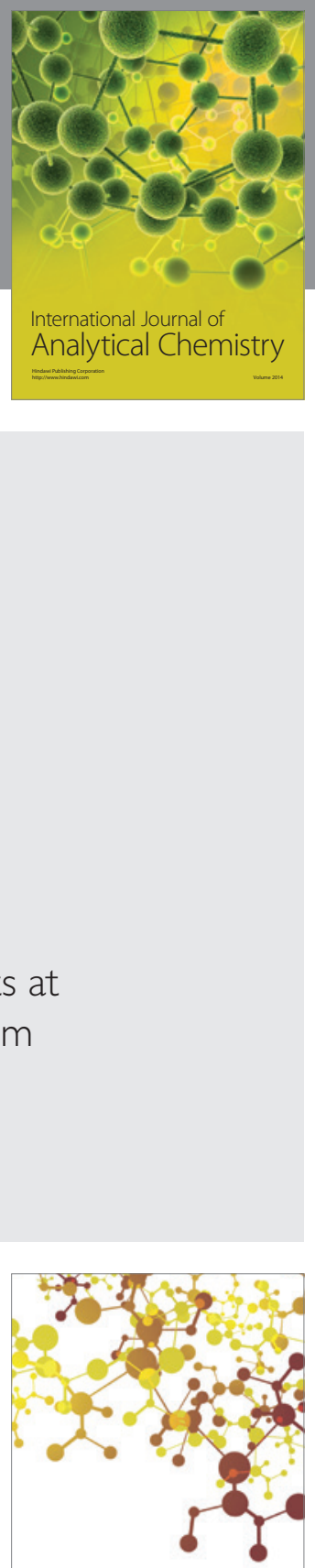

Journal of

Applied Chemistry
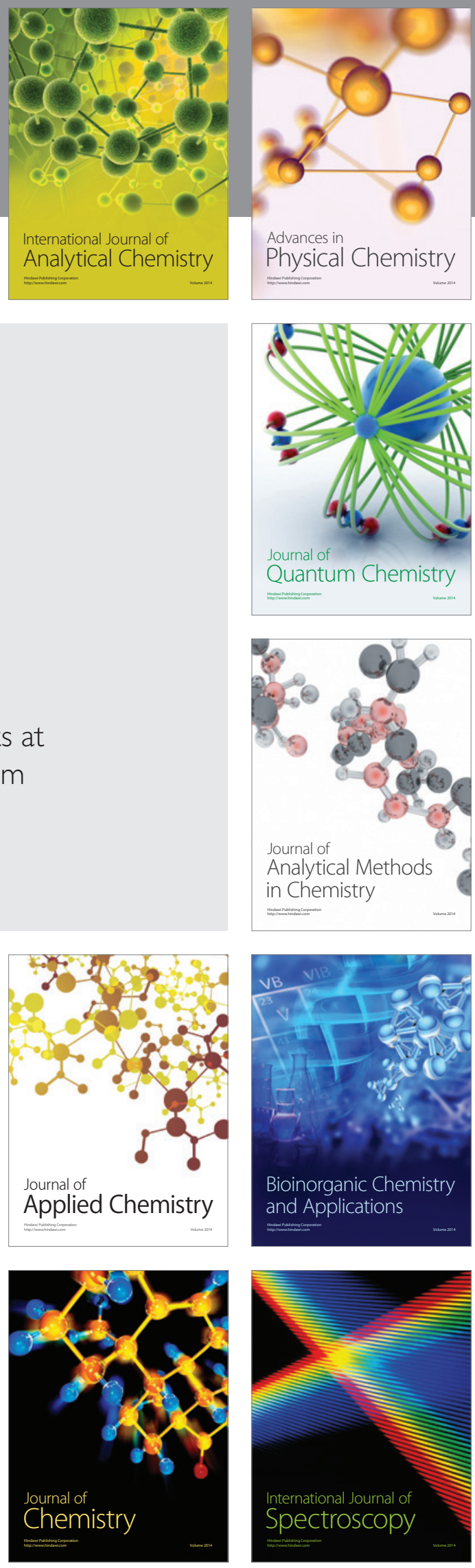